\title{
The Reason Why the Companion Ibn Abbas Changed His Opinion on Riba Al-fadhl
}

\author{
Ibrahim Nuhu Tahir
}

\begin{abstract}
This paper aims to explain an important element that should be avoided in business dealings for them to be permissible in Islam. The interest to conduct this research was inspired by a fatwah given by some contemporary scholars. The fatwah states that Riba al-Fadhl does not exist in currency exchange, hence the topic. The objective of this research is to disclose the truth of the matter. In addition it aims to rouse the awareness of people of concern and to draw their attention to what really happened during the early days of the companions regarding the said issue. The reader is presented with clear evidence that shows that the above fatwa is wrong. The Prophet (sallallahu alaihi wasallam) said: "Gold for gold, silver for silver, wheat for wheat, barley for barley, dates for dates, and salt for salt - like for like, equal for equal, and hand-to-hand; if the commodities differ, then you may sell as you wish, provided that the exchange is hand-to-hand."
\end{abstract}

Index Terms - Riba al-fadhl, riba al-nasi'ah, abdullah ibn abbas and sarf.

\section{INTRODUCTION}

To proceed, it is known to every Muslim familiar with the Islamic way of doing business that Riba is strongly prohibited and dealing in it is a major sin in Islam. In fact it is categorized by the Sunnah to be among the seven most destructive sins, The Prophet said (sallallahu alaihi wasallam):

"Beware of the seven most destructive sins" He was asked, "What are they O messenger of Allah?" He said: "Associating partners with Allah, magic, killing a soul whom Allah has forbidden to be killed, except with just cause, consuming Riba; and chaste and good believing woman, who never think of anything touching their chastity..." [1].

The Prophet also said (sallallahu alaihi wasallam):

"Allah cursed whoever consumes Riba, whoever pays Riba, the two who are witnesses to it, and the scribe who records it" [2].

In another place the Prophet, (sallallahu alaihi wasallam):

"A dirham of riba which a man receives knowingly is worse than committing adultery thirty-six times". Bayhaqi has also reported the above hadith in Shuab al-Iman with the addition that, "Hell befits him whose flesh has been nourished by the unlawful" [3].

In another place the Prophet, (sallallahu alaihi wasallam), said:

Manuscript received November 18, 2013; revised February 28, 2015. Ibrahim Nuhu Tahir is with the Kulliyyah of Economic and Management Science, Department of Economic, IIUM, Selangor, Malaysia (e-mail: ibrahimnuhu@iium.edu.my).
"Riba has seventy segments, the least serious being equivalent to a man committing adultery with his own mother" [4].

In another place the Prophet, (sallallahu alaihi wasallam) said:

"There will certainly come a time for mankind when everyone will take riba and if he does not do so, its dust will reach him" [5].

Abu Umamah narrated that: The Prophet, (sallallahu alaihi wasallam) said: "Whoever makes an intercession for his brother and accepts a gift offered by him has entered riba through one of its large gates" [6].

Therefore it does not come as a surprise to witness the strict way Qur'an has treated dealings of riba: Allah says:

"O you who believe! Be afraid of Allah and give up what remains (due to you) from Riba (from now onward), if you are (really) believers". And if you do not do it, then take a notice of war from Allah and His Messenger [sal-Allahu 'alayhi wa sallam] but if you repent, you shall have your capital sums. Deal not unjustly (by asking more than your capital sums), and you shall not be dealt with unjustly (by receiving less than your capital sums),[002.278-279].

Based on the above mentioned evidences and many others that have not been mentioned, the scholars unanimously agreed that Riba is one of the major sins in Islam. This is the holistic perspective on the issue. However there are a few specific issues that are controversial when it comes to their details. One of those areas where controversy exists or used to exist is Riba al-Fadhl. It has been reported that Abdullah ibn Abbas (May Allah be pleased with him) was of the opinion that Riba only exists in Nasi'ah and not Fadhl. Insha'Allah this article assesses whether or not his opinion is correct, and whether or not this eminent companion died upon this view.

\section{THE REASON BEHIND THE ARTICLE}

The interest to conduct this research was a result of some fatwahs given by some scholars of this contemporary era. The fatwah says that Riba al-Fadhl does not exist in currency, hence the selection of this topic. The objective of this research is to disclose the truth of the matter. Similarly to awaken the awareness of people of concern and to draw their attention on what really happened during the early days of the companions regarding the said issue.

\section{Methodology}

The writer will begin with a short biography on Abdullah 
ibn Abbas (May Allah be pleased with him), this will be succeeded by the following topics: Definition of Riba, Types of Riba, The opinion of Abdullah ibn Abbas (May Allah be pleased with him) on Riba al-Fadhl, An analysis on the evidence used by the two approaches, Preference by the researcher, Conclusion and Recommendations given by the researcher and then the reference referred to by the writer in this article.

\section{A SHORT BIOGRAPHY OF ABDULLAH IBN ABBAS}

Abdullah ibn Abbas was one of the most prominent companions of the Prophet (sallallahu alaihi wasallam), the sheikh of this Ummah, and a great scholar in Tafseer. He was the son of the Prophet's Uncle, Abbas ibn Abdulmuttalib. He was born three years before the hijra of the Prophet (sallallahu alaihi wasallam). He accompanied the Messenger of Allah for about thirty months before his demise; he was able to narrate a number of Ahadith from him before he died. He also took several Ahadith from many other companions. The Prophet (sallallahu alaihi wasallam) died when ibn Abbas was at the young age of ten, some said at the age of 15 and some said otherwise. The Prophet (sallallahu alaihi wasallam) prayed to Allah to grant him wisdom and knowledge. Because of this concern from the Prophet (sallallahu alaihi wasallam), ibn Abbas was blessed by Allah with an extensive amount of knowledge in the area of Tafseer, Sunnah, Fiqh, language and many others. Abdullah ibn Abbas (May Allah be pleased with him) died in year sixty eight of Hijrah at the age of seventy one (May Allah have mercy upon him) [7].

\section{DEFINITION OF RIBA}

The word Riba literally means increase, addition and excess. Linguistically when this word is mentioned an Arab man understands increase [8].

When dealing with the technical definition the meaning cannot be understood properly without knowing the classification of Riba under the Fiqh al-Islami. The scholars have divided Riba into two different types: Riba al-Fadhl and Riba al-Nasi'ah

\section{RIBA AL-FADHL}

Riba al-Fadhl refers to an increase in one of the two exchanged ribawi items that are of the same nature and type [8]. These items are those stated by the following hadith: The Prophet (sallallahu alaihi wasallam) prohibited this type of Riba in the Hadith narrated by Ubadah ibn al-Samit that the messenger of Allah (sallallahu alaihi wasallam) said: "Gold for gold, silver for silver, wheat for wheat, barley for barley, dates for dates, and salt for salt-like for like, equal for equal, and hand-to-hand; if the commodities differ, then you may sell as you wish, provided that the exchange is hand-to-hand" [9]. said:

In another place the Prophet, (sallallahu alaihi wasallam),

"Do not sell gold for gold except when it is like for like, and do not increase one over the other; do not sell silver for silver except when it is like for like, and do not increase one over the other; and do not sell what is away [from among these] for what is ready". Another narration says, "Gold for gold, silver for silver, wheat for wheat, barley for barley, dates for dates, and salt for salt - like for like, and hand-to-hand. Whoever pays more or takes more has indulged in riba. The taker and the giver are alike [in guilt]" [10].

\section{RIBA AL-NASI'AH}

This type of Riba refers to a stipulated and fixed increase over and above the loan amount that a debtor agrees to pay his creditor in relation to a specific period of time [11]. Jabir ibn Abdullah, reported that on the Prophet's Farewell Pilgrimage: The Prophet, peace and blessings of Allah be on him, addressed the people and said: "All of the riba of Jahilliyyah is annulled. The first riba that I annul is our riba, that accruing to Abbas ibn Abd al-Muttalib [the Prophet's uncle]; it is being cancelled completely. [12] In another place the Prophet, (sallallahu alaihi wasallam), said: "There is no riba except in Nasia'h [waiting]" in Sahih Muslim it is said "There is no riba in hand-to-hand [spot] transactions" [13].

\section{THE OPINION OF ABDULLAH IBN ABBAS ON RIBA AL-FADHL}

Although it is a consensus of the scholars that Riba is haram, they differ when it comes to what constitutes Riba and what does not. They all agreed that Riba al-Nasia'h is prohibited. The only argument that exists is on the acceptance of Riba al-Fadhl. The argument is between the majority of the scholars on one side and Abdullah ibn Abbas and a minority on the other side. This issue is of greatest concern compared to other issues in riba as people are unknowingly falling into Riba. In this article the focus is on the opinion of Abdullah ibn Abbas. The following are details of the two opinions and their evidences.

\section{A. The View of the Majority}

Majority of the scholars believe that both types of Riba (al-Fadh and al-Nasi'ah) exist in the six items mentioned by the Prophet in the hadith of Ubadah ibn al-Samit. A person cannot exchange gold with another gold with excess in one of them, both pieces of gold have to be the same weight. Likewise the payment has to be prompt and on the spot. Any delay in payment or increase in one of the exchanged items is Riba which will render the dealings haram.

\section{B. The View of Abdullah ibn Abbas}

Ibn Abbas said that there is no Riba al-Fadh and only Riba al-Nasi'ah exists. He said that as long as two people exchange gold and make the payment at the same time, the transaction is halaal even if 5 grams is being exchanged for 1 gram.

\section{The Evidence of the Majority}

The majority used three types of evidence: Qur'an, Sunnah and Ij'maa'. They use the statement of Allah in Qur'an,

"Allah has permitted trading and forbidden Riba" [002.275].

The word al-Riba is designed in a way that includes every type of Riba, this is understood and inferred because of the 
letters " $A L$ " that the word is adorned with. Linguistically whenever a word is strapped with these letters " $A L$ ", comprehensiveness and generality is understood. Therefore the prohibition of Riba in this verse is general and thus includes both types of Riba (al-Fadhl and Nasi'ah) [14].

As for their evidence from the Sunnah, firstly, they quote the two previously mentioned Ahadith: the hadith of Ubadah ibn al-Samita and that of Abu Saiid al-Khudri. In addition they reason using the following Ahadith:

Abu Sa'id and Abu Hurayrah narrated that: A man employed by the Prophet, (sallallahu alaihi wasallam), in Khaybar brought him janibs [dates of very fine quality]. Upon the Prophet's asking him whether all the dates of Khaybar were such, the man replied that this was not the case and added that they exchanged a sa ' [a measure] of this kind for two or three [of the other kind]". The Prophet, (sallallahu alaihi wasallam), replied, "Do not do so. Sell [the lower quality dates] for dirhams and then use the dirhams to buy janibs." [When dates are exchanged against dates] they should be equal in weight" [15].

Abu Sa'id narrated that: Bilal brought to the Prophet (sallallahu alaihi wasallam), some barni [good quality] dates whereupon the Prophet (sallallahu alaihi wasallam) asked him where these were from. Bilal replied, "I had some inferior dates which I exchanged for these - two sa's for a sa'" The Prophet (sallallahu alaihi wasallam) said, "Oh no, this is exactly riba. Do not do so, but when you wish to buy, sell the inferior dates against something [cash] and then buy the better dates with the price you receive" [16].

Fadalah bin Ubayd al-Ansari narrated that: On the day of Khaybar he bought a necklace of gold and pearls for twelve dinars. On separating the two, he found that the gold itself was equal to more than twelve dinars. So he mentioned this to the Prophet (sallallahu alaihi wasallam), who replied, "It [jewellery] must not be sold until the contents have been valued separately" [17].

As for the consensus, Imam al-Nawawi, Yahya ibn Hubairah, Ibn Hajar al-Haitami and Imam al-Qurtubi all narrate that the scholars have unanimously agreed that both types of Riba exist in those items mentioned by the Sunnah. Therefore, it is not permissible to exchange gold with gold while one of them is more in quantity than the other. Similarly, if the exchange between gold and gold takes place, the payment cannot be delayed. The consensus is based on the above mentioned verse together with the hadith of Ubadah and Abu Said [18].

\section{The Evidence of Abdullah ibn Abbas}

The scholars have mentioned that Ibn Abbas depended on the hadith of Usamah and al-Bara' ibn Azib:

Usamah ibn Zayd: The Prophet, (sallallahu alaihi wasallam), said: "There is no riba except in nasi'ah [waiting]" in another narration: "There is no riba in hand-to-hand [spot] transactions"(Al-Nasa'i 50).

Abu al-Munhal said: "My partner in Kufa sold and exchanged Dirhams with other Dirhams with increase in one of them. I told him: I don't think this type of dealing is allowed in Islam. He replied saying I did that in a market place and nobody had any objection towards that. Then I went to al-Bara' ibn Azib and asked him about that. Al-Bara' said that the Prophet (sallallahu alaihi wasallam) had arrived in Madinah while our trade is like that. The Prophet (sallallahu alaihi wasallam) said: "There is no problem in whatever exchange takes place hand to hand and on the spot. And if the payment is delayed there is no good in such dealing at all." And then he said: go and ask Zaid ibn Arqam about the issue because he does business more than me. I then went to him and he told me that al-Bara had spoken the truth." Imam al-Humaidi one of the narrators of this hadith said after narrating it: "This hadith has been abrogated; therefore it should not be used" [19].

It can be seen that the above quotations support that Riba only exists in Nasi'ah and not al-Fadh, which is the reason why ibn Abbas used to hold that what is haram is Riba al-Nasi'ah not al-Fadhl.

\section{An ANALYSIS ON THE EVIDENCE USED to SUPPORT THE TWO VIEWS}

As it is understood from the above, majority of the scholars supported their argument in three ways: Qur'an, Sunnah and Ijma'. Their deduction from these sources is very clear. However, the use of these sources by the majority to prove the existence of Riba al-Fadhl has been criticized by others. This criticism can be summarized as follows:

Their argument is that the word al-Riba mentioned in the verse is not general and thus does not include everything. They say that according to the language, preceding a word with " $A L$ " is not only used by the Arabs to address all possibilities of that nature. It has other uses. For example, in our case some scholars among the Mafassirin believe that the " $A L$ " in the word al-Riba is not used to address generality but is instead used to address a specific objective which is the meaning known to the Arabs. The Arabs used to deal with riba al-Nasi'ah and not al-Fadhl. Therefore, whenever this word is used by any of the two primary sources, the first thing that will come to mind is what is known to them to be Riba. According to them, the existence of this type of assumption means the verse cannot be a clear evidence to support the prohibition of Riba al-Fadhl.

They also claim that the verse which deals with Riba al-Fadhl was revealed before the one in surah al-Baqarah. Instead, to them, the first verse to be revealed is the saying of Allah:

O you who believe! Eat not Riba doubled and multiplied, but fear Allah that you may be successful, [003:130].

If this could be proven it would act as a clear indicator that when Qur'an talks about Riba in Surah al-Baqarah, Allah is referring to the Riba that exists in their mind and that is the Nasi'ah.

This is the answer given by the minority to refute the majority in their view that Riba in the saying of Allah: "Allah has permitted trading and forbidden Riba." [002.275] includes al-Fadhl as well as Nasi'ah believing that the word " $A L$ " is for generality.

Moreover, they also commented on the other type of 
evidence used by the majority which is the hadith of the Prophet (sallallahu alaihi wasallam). Their argument is that the prohibition mentioned in these Ahadith is not intended. What is intended by that prohibition is Karaahah (dislike). According to them this is how the two Ahadith can be reconciled and used.

The last refutation is about the issue of Ijma' mentioned by the majority. This is also rejected by the opponents. Ibn Hazm said: "The most amazing and surprising thing is the claim by some scholars that the scholars unanimously agreed that analogy can be used to include other items other than those mentioned by the hadith. This is not true, by Allah there is no authentic Ijma' on the six items mentioned by the hadith. Did not ibn Abbas and ibn Mas'ud used to believe that there is no Riba in any exchange that takes place between two ribawi items on the spot or hand to hand. This is also the opinion of Ataa' and the disciples of ibn Abbas and many scholars in Makkah."

The majority of the scholars gave an answer to the evidence used by ibn Abbas. They responded to this opinion in three ways:

\section{A. By Interpretation}

In this regard the majority said there is no contradiction between the narrations, the hadith of Usamah deals with the situations whereby the exchange is between two ribawi items where that increase in one of them is allowed, for example gold against silver. In this regard exchange with excess in one of them is permissible as long as the parties finalized the dealing before they go their separate ways.-This means each one of them receives his right before they depart. They are forced to use this interpretation due to the fact that the Sunnah of the Prophet (sallallahu alaihi wasallam) is very authentic in prohibiting Riba al-Fadhl as well as Nasi'ah.

Another interpretation says the hadith of Usamah is referring to the legality of exchange between two ribawi items of similar nature and type. It is halaal if there is no increase in one of the exchanged items and the parties don't separate before due rights are given to the respective parties. The dealing is halaal, but the delay in payment is prohibited which is the Nasi'ah that Abdullah ibn Abbas is talking about.

Another interpretation says the scope of Usamah's hadith extends beyond transactions in ribawi; rather it addresses other types of dealings that are prohibited by the Shari'ah like the sale of debt with debt.

Another interpretation says the meaning of Usamah's hadith is maintained. The hadith addresses Riba issues with emphasis on Riba al-Nasi'ah. Hence this interpretation facilitates the reconciliation and use of all the Ahadith. This type of expression exists in the Qur'an in many places. Allah says:

The believers are only those who, when Allah is mentioned, feel a fear in their hearts and when His Verses (this Qur'an) are recited to them, they (i.e. the Verses) increase their Faith; and they put their trust in their Lord (Alone); [008:002]

The word 'believers' here means those who possesses a complete faith and Imaan. It does not mean the rest are non-believers. Therefore, according to this hadith of Usamah the greatest Riba is that of Nasi'ah.

\section{B. By Abrogation}

Imaam al-Nawawi said: The scholars of Islam unanimously agreed that Usamah's hadith should not be applied. Moreover, there are narrations from the companions indicating that the prohibition of Riba al-Fadhl took place during the last part of Prophet Muhammad's life (sallallahu alaihi wasallam) [20]. Below are a few of those Ahadith:

Fadalah bin Ubayd al-Ansari narrated that: On the day of Khaybar he bought a necklace of gold and pearls for twelve dinars. On separating the two, he found that the gold itself was equal to more than twelve dinars. So he mentioned this to the Prophet, peace be on him, who replied, "It [jewellery] must not be sold until the contents have been valued separately". In another narration Fadalah said: The Prophet (sallallahu alaihi wasallam) commanded that the gold that was attached to the necklace should be removed first, then he said: "When gold is exchanged with gold equality has to be confirmed." Another narration says, "After that the Prophet (sallallahu alaihi wasallam) prohibited the sale of althe golden necklace before the gold is separated" [21].

Abu Sa'id and Abu Hurayrah narrated that: A man employed by the Prophet (sallallahu alaihi wasallam), may the peace and blessings of Allah be upon him, in Khaybar brought for him janibs [dates of very fine quality]. Upon the Prophet's asking him whether all the dates of Khaybar were such, the man replied that this was not the case and added that they exchanged a sa '[a measure] of this kind for two or three [of the other kind]". The Prophet, (sallallahu alaihi wasallam) replied, "Do not do so. Sell [the lower quality dates] for dirhams and then use the dirhams to buy janibs." [When dates are exchanged against dates] they should be equal in weight" [22].

Abu Sa'id narrated that: Bilal brought to the Prophet (sallallahu alaihi wasallam), some barni [good quality] dates whereupon the Prophet (sallallahu alaihi wasallam) asked him where these were from. Bilal replied, "I had some inferior dates which I exchanged for these - two sa's for a sa:" The Prophet (sallallahu alaihi wasallam) said, "Oh no, this is exactly riba. Do not do so, but when you wish to buy, sell the inferior dates against something [cash] and then buy the better dates with the price you receive" [23].

These Ahadith clearly indicate that the permissibility of Riba al-Fadhl was only there during the early days of Hijra. It used to be halaal and then Allah made it prohibited as it can be seen from the previous quotations.

\section{By Preference}

The last method used by the majority to respond to ibn Abbas is known by the scholars as tarjih which means to prefer one opinion over the other. They prefer their evidence over that of ibn Abbas using the following ways:

1) The number of companions who narrated the hadith of the majority significantly exceeds those who reported that of ibn Abbas. The evidence used by the majority is narrated by Abu Bakr, Umar, Uthman, Abu Hurairah, Hisham ibn Amir, al-Bara' Zaid ibn Arqam, Fadhaalah ibn Ubaid, Abu Bakrah, Ibn Umar, Abu al-Darda', Bilaal and Abu Sai'd al-Khudri. All of their narrations are 
authentic and they clearly stated that Riba al-Fadhl is prohibited. As for the evidence used ibn Abbas, it is narrated by one companion and that was Usamah.

2) Secondly, the narrations of the majority are very clear in their meaning and application, whereas the narration of Usamah gives the intended meaning by ibn Abbas through the way of inference. The maxim says, "al-Mantooq muqaddamun ala al-Mufhoom", which means the literal meaning is preferred over the figurative meaning. The hadith of the majority gives its ruling through the way of mantooq, whereas the other hadith used by the minority gives it through deductions and inferences.

3) Thirdly, they say that the hadith of Usamah is Aam which means general whereas that of the majority is khaas specific. The maxim says whenever there is a contradiction between general and specific, the ruling is to go for the specific.

As for the second hadith used by the minority to support their view, the majority refuted this evidence in two ways:

1) The hadith has been abrogated. The narrators of that hadith have clearly stated that the hadith was said by the Prophet (sallallahu alaihi wasallam) upon his arrival in Madinah.

2) The narration used by ibn Abbas is weak due to shudhudh (going against the norm). There are three chains of narration for the hadith of al-Bara' used by Ibn Abbas. Two of them agree with the majority whereas the narration used by ibn Abbas is the only one that goes against the majority. This forces us to conclude that the meaning of the hadith is applied to the sale of two different types of ribawi items with increase which is halaal as long as the payment is prompt and on the spot. In Sahih al-Bukhari Abu al-Minhal said, "I asked al-Bara' ibn Azib and Zaid ibn Arqam about the conversion (of Gold and Silver) and both of them said it is not allowed to exchange gold with silver on credit.

\section{RESEARCHER's PREFERENCE}

Careful analysis shows that the opinion of the majority is the truth, which says that Riba is prohibited in both Fadhl and Nasi'ah. The basis of this preference is as follows:

1) The amounts of the narrations prohibiting Riba al-Fadhl are more than those validating it. As mentioned earlier the prohibition is narrated by Abu Bakr, Umar, Uthman, Abu Hurairah, Hisham ibn Amir, al-Bara' Zaid ibn Arqam, Fadhaalah ibn Ubaid, Abu Bakrah, Ibn Umar, Abu al-Darda', Bilaal and Abu sai'd al-Khudri. Hence a consensus among the scholars is narrated by some.

2) The meanings of the Ahadith of prohibition are very clear and they do not need additional inferences to give the intended meaning. On the contrary, inference is needed to derive the intended meaning to support the opposing view.-Because the saying of the Prophet (sallallahu alaihi wasallam), "There is no Riba except in Nasi'ah" does not mean Riba only exists in Nasi'ah. This is similar to the Arabs saying, 'There is no scholar except Zaid.' They never meant that "No scholar exists except Zaid." They only meant that he has more knowledge than everybody else [24].

3) It has been confirmed that some of those who believe that Riba only exists in Nasi'ah and not in Fadhl changed their view in that regard before their death. The best example from among them is ibn Abbas who is the most famous person to have held this view. The following hadith explains this fact: Abu Nadra reported: I asked Ibn Umar and Ibn Abbas (Allah be pleased with them) about the conversion of gold with gold but they did not find any harm in that. I was sitting in the company of Abd Sa'id al-Khudri (Allah be pleased with him) and asked him about this exchange, and he said: Whatever is addition is interest. I refused to accept it on account of their statement (statement of Ibn 'Abbas and Ibn 'Umar). He said: I am not narrating to you except what I heard from Allah's Messenger (sallallahu alaihi wasallam). There came to him the owner of a date-palm with one sa' of fine dates, and the dates of Allah's Apostle (sallallahu alaihi wasallam) were of that colour. Allah's Apostle (sallallahu alaihi wasallam) said to him: Where did you get these dates? I went with two sa's of (inferior dates) and bought one sa' of (these fine dates), for that is the prevailing price (of inferior dates) in the market and that is the price (of the fine quality of dates in the market), whereupon Allah's Messenger (sallallahu alaihi wasallam) said: Woe be upon you! You have dealt in interest, when you decide to do it (i. e. exchange superior quality of dates for inferior quality); so you should sell your dates for another commodity (or currency) and then with the help of that commodity buy the dates you like. Abu Sa'ad said: When dates are exchanged for dates (with different qualities) there is the possibility (of the element of) interest (creeping into that) or when gold is exchanged for gold having different qualities. I subsequently came to Ibn 'Umar and he forbade me (to do it), but I did not come to Ibn 'Abbas; (Allah be pleased with them). He (the narrator) said: Abu as-Sahba' narrated to me: He asked Ibn Abbas (Allah be pleased with them) in Mecca, and he too disapproved of it [25].

4) In another narration Hayyan ibn Ubaidullah al-Adawi, Abu Zuhair said: I witnessed the moment Lahiq ibn Humaid Abu Mijlaz was asked about al-Sarf (money exchange). He said: Abdullah ibn Abbas long ago used to believe that it is ok and permissible. This remained until the time Abu Saiid al-Khudri met him and he said O Abdullah ibn Abbas fear Allah! Until when are you going to stop validating riba for people, didn't it reach you that the Prophet (sallallahu alaihi wasallam) said one day when he was with his wife Umm Salamah, "I desire Ajwah dates." Upon knowing that, Umm Salamah said I sent two Sa's of Aqiq dates to the house of one of the brothers from among the Ansar, they exchanged my two Sa's dates with one Sa' of Ajwah date. I gave them to the Prophet (sallallahu alaihi wasallam) and he was so amazed with it. He took one date, ate it then held it and said to them, from where did you get this? She said I sold two Sa's from the dates of Aqiq to the house of so and so and they gave us instead one Sa'a of this. Upon hearing this he threw away the date that was in his hand and he 
said; "Take it back, take it back, I have no need for it. Date with date, wheat with wheat, barley with barley, gold with gold, and silver with silver whenever they are exchanged hand to hand equality has to be confirmed without increase or decrease. Definitely he dealt in usury and likewise everything that is weighed or measured. Ibn Abbas said you have reminded me oh Abu Sa'eed an issue that I had forgotten, I seek the forgiveness of Allah and I repent to Him. After this ibn Abbas used to be very strict in forbidding people from taking riba al-fadhl. (Al-Baihaqi).

This is clear evidence that no companion died upon this opinion.

\section{CONCLUSION}

The evidences and analysis provided by the researcher are sufficient to show that the correct opinion is that all types of Riba are prohibited. Therefore the evidence used by Ibn Abbas and who ever follows him among the contemporary jurists should not be applied. The main purpose of this article was to provide the public with clear evidence on this issue and to facilitate their avoidance of Riba, a major sin in Islam. It is always best to be on the safe side, and the safe side here is in following the view of the majority which forbade all forms of Riba based on un-doubtful evidence. Therefore the writer is humbly inviting those contemporary scholars who are hastening toward giving fatwah before they fully study the issue thoroughly to apply the words of Allah when He says in Qur'an:

"And follow not (O man, i.e., say not or do not or witness not) that of which you have no knowledge. Verily, the hearing, and the sight, and the heart of each of those ones will be questioned (by Allah)" [017:036].

\section{REFERENCES}

[1] A. Baihaqi and A. H. Aliyyu, The Great Prophetic Traditions (Al-Sunan Al-Kubra), Makkah: Dar al-Baz, 1994, p. 37.

[2] M. Al-hajjaj, The Authentic Prophetic Traditions (Sahih Muslim), Riyadh: Ri'asat Idarat al-Buhuth al-Ilmiyyah wa al-Ifta', p. 1218.

[3] A. Baihaqi and A. Al-hussain, The Branches of Faith (Shu'ab al-Iman). Beirut: Dar al-Kutub al-'ilmiyyah, ch. 38, p. 362, 2010.

[4] A. Tabarani and S. Ahmad, The Index of Tabarani (Al-Mu'jam al-Tabaran)i, Al-Qahirah: Dar al-Haramain, p. 158.

[5] A. Dawud and S. A. Al-sijistaanee, Prophetic Traditions (Sunan Abi Dawud), Beirut: Dar Al-Fikr, ch.3, p. 220, 1969.

[6] A. Ruwayyani and M. Harun, Compilation of Prophetic Traditions (Musnad al-Ruwayyani), Al-Qahirah: Mu'assasat Qurtuba, p. 289, 1916.
[7] A. Dhahabi and A. A. A. M. Ahmad, The Biographies of the Noble Predecessors (Siyaru A'lam al-Nubala'), Lebanon: Mu'assasat al-Risalah, pp. 331-359, 1985.

[8] U. Abdul-aziz, Usury and Financial Dealings under Islamic Law (Al-Riba wa al-Mua'malat al-Masrafiyyah Fi Nazar al-Shari'ah), Riyadh: Dar al-Asimah, p. 37, 1918.

[9] M. Al-hajjaj, The Authentic Prophetic Traditions (Sahih Muslim), Riyadh: Ri'asat Idarat al-Buhuth al-Ilmiyyah wa al-Ifta', p. 1211.

[10] I. Jarud and A. Aliyu, The Selected Traditions (Al-Muntaqa Min al-Sunan al-Musnadah), Beirut: Mu'assasat al-Kitab al-Thaqafiyyah, p. $163,1988$.

[11] Y. Saleem, Islamic Commercial Law, Singapore: John Wiley \& Sons, p. 2, 2013.

[12] I. Majah and M. Y. Al-qazwini, Prophetic Traditions (Sunan Ibn Majah), Halab: Dar Ihya' al-Kutub al-Arabiyyah, p.1022.

[13] A. Nasa'i and A. Shu'aib, Prophetic Traditions (Sunan al-Nasa'i), Beirut: Mu'assasat al-Risalah, p. 50, 2001.

[14] U. Abdul-aziz, Usury and Financial Dealings under Islamic Law (Al-Riba wa al-Mua'malat al-Masrafiyyah Fi Nazar al-Shari'ah), Riyadh: Dar al-Asimah, pp. 37-56, 1918.

[15] M. Anas, Ready to be used narration of Yahya (Muwatta al-Imam Malik Riwayat Yahya, Beirut: Dar al-Kutub al-'Ilmiyyah, p. 623, 1984.

[16] A. Hanbal, Compilation of Prophetic Traditions (Musnad Al-Imam Ahmad), Beirut: Mu'assasat Al-Risalah, p. 139, 1999.

[17] A. Tirmidhi and M. I. Sawra, Prophetic Traditions (Sunan al-Tirmidhi), Beirut: Dar Ihya'i al-Turath, p. 548.

[18] U. Abdul-aziz, Usury and Financial Dealings under Islamic Law (Al-Riba wa al-Mua'malat al-Masrafiyyah Fi Nazar al-Shari'ah), Riyadh: Dar al-Asimah, p. 61, 1918.

[19] A. Baihaqi and A. H. Aliyyu, The Great Prophetic Traditions (Al-Sunan Al-Kubra), Makkah: Dar al- Baz, p. 48, 1994.

[20] U. Abdul-aziz, Usury and Financial Dealings under Islamic Law (Al-Riba wa al-Mua'malat al-Masrafiyyah Fi Nazar al-Shari'ah), Riyadh: Dar al-Asimah, pp. 65-73, 1918.

[21] A. Tirmidhi and M. I. Sawra, Prophetic Traditions (Sunan al-Tirmidhi), Beirut: Dar Ihya'i al-Turath, p. 548.

[22] A. Baihaqi and A. H. Aliyyu, The Great Prophetic Traditions (Al-Sunan Al-Kubra), Makkah: Dar al- Baz, p. 468, 1994.

[23] A. Bukhari and M. Isma'il, The Authentic Prophetic Traditions ( Sahih Al-Bukhari), Beirut: Dar Al-Fikr, p. 101, 1922.

[24] U. Abdul-aziz, Usury and Financial Dealings under Islamic Law (Al-Riba wa al-Mua'malat al-Masrafiyyah Fi Nazar al-Shari'ah), Riyadh: Dar al-Asimah, pp. 72-76, 1918.

[25] M. Al-hajjaj, The Authentic Prophetic Traditions (Sahih Muslim), Riyadh: Ri'asat Idarat al-Buhuth al-Ilmiyyah wa al-Ifta', p. 1217.

Ibrahim Nuhu Tahir was born in Zaria, Nigeria on April 19, 1977. He graduated with B.A degree (first class of honours) in Shari'ah and Islamic studies in the Kulliyyah of Shari'ah in the International Islamic University of Al'Madinah Al'Munawwarah and a postgraduate diploma (first class of honours) in Islamic law and Islamic political science from the same university. He then proceeded to earn a masters in Shari'ah and civil laws from the International Islamic University of Malaysia. Thereafter he obtained his Ph.d in Shari'ah and civil laws from the same university where he now works as assistant professor in the Kulliyyah of Economics and Management Sciences in the Department of Economics. 